DOI: $10.29064 /$ ijma.689652

\title{
THE ROLE OF GOOD GOVERNANCE PRACTICE ON CONFLICT RESOLUTION: A CASE OF BENADIR MUNICIPALITY, MOGADISHU-SOMALIA
}

\author{
Abukar Gacal Alasow ${ }^{1}$ \\ Prof. Dr. Kamil Ufuk BILGIN ${ }^{2}$
}

\begin{abstract}
The primary role of government exists is to provide service to the citizens. Serving to the people is the main function of any state. Accordingly, the local government is the third level of government layers after the central and state level. Local government exists to bring closer to low-level people and remote areas. The primary aim of this article was to explore the role of good governance practice on conflict resolution at the local level, a case study of Benadir municipality. This study carried out four objectives: The role of local government public participation, accountability, transparency and equity on conflict resolution in Benadir municipality. The quantitative method was used as a research design in this study. Furthermore, descriptive statistics and inferential statistics were analyzed to know the relationship between variables. Mean, standard deviation, correlation, regression, ANOVA table, and coefficient determination were reported in the study. The study found that the local government's public participation, accountability, and transparency have a statistically positive impact on conflict resolution in Benadir municipality while the equity variable has a weak negative correlation with the conflict resolution in the context of the study. If greater participation, accountability, transparency, and equity exist in general society particularly public officers and authoritative bodies at a local level, the higher the degree of good governance will be an effective conflict resolution is achieved.
\end{abstract}

Key Words: Good Governance, Local Conflict Resolution, Local Participation, Local Transparency, Benadir Municipality

\footnotetext{
${ }^{1}$ Department of Political Science and Public Administration, Ankara HBV University, Turkey; e-mail: gacalabuukar@gmail.com

${ }_{2}^{2}$ Faculty Member, Political Science and Public Administration, Ankara Hacı Bayram Veli University, Turkey, kamil.bilgin@hbv.edu.tr
} 


\section{INTRODUCTION}

The term good governance came into view at the beginning of the 1980s as a tool for poverty reduction and sustainable development. By the time it appeared this concept many governments especially developed countries, international organizations, as well as regional organizations, have acknowledged its importance as a tool of development. Toward the last decades of the twentieth century, and the first decades of the twenty-first century the idea of governance has taken on a focal part in contemporary discussions in the field of social science and especially in the department of public admin. The idea has been utilized much of the time, however frequently with very various meanings and suggestions (Katsamunska, 2000).

The notion of good governance had become controversial over the last thirty years and the measurement tool used to measure how governments or states exercised their power. The term "good" denotes the meaning of government to do activities in a good manner. The term governance is a comprehensive meaning with ample implications. This concept has been using before many decades since the fourteenth century and has two different meaning depending on the angle which is looked. For the first side, it relates approaches of governing, another side relates actions and the ways of governing (Khan, 2006: 19). Good Governance is a vital modern system that allows relations between rulings and ruled in setting up the accomplishment of key goals.

In this contemporary world, no government or/and any other public organizations can uphold position except it guarantees that different organization is active in the citizen's demand at any time and everywhere, this serving to people is one of the impressive activities of every state regardless political structure is subjected; democratic or autocratic system, every citizen has rights to the fundamental services that government provides. The third layer of the government structure - local government - regularly plays a vast role in administering providing service to the public in the name of the central government, these activities including but not restricted to security, education, licensing, healthcare, city planning, etc. (Anna \& Lissa, 2016). The connections of participation, transparency, and accountability between the government and its citizens determine the quality of service delivery results.

In the meantime, one of the main important issues of government is to ensure the quality of service that provides different institutions. Easy to get, inexpensive and timely conveyed service is vital for all governments to develop the standard of living of the people and creating a confidence situation, and that is the reason many governments are newly focusing to the citizenoriented (William, Victor, Krista, Piret, \& Lars, 2017). This collaboration allows all parts to mutually tackle public institution's issues, furthermore, this strategy is viewed as an important idea that gives people a platform to take part decision-making process that affects their lives, generally, decisions concern what service to supply and how greatest to provide.

Postcolonial Somali history dates from 1960, when the previous Italian settlement of Somalia and the British protectorate of Somaliland in the north, joined to shape the Somali Republic. English Somaliland got freedom on June 26, 1960, while Italian Somalia picked up autonomy on 1 July 1960, which is additionally the date on which the two shaped the Somali Republic. North and Southern parts were united 1st July 1960 and formed the Republic of Somalia. Before the collapse of the central government of Somalia in 1991, Somalia consisted of 18 regions of 
administration. Banadir Regional Administration (BRA) was one of those regions. Somali provisional constitution article number 48, 1(b) determines the structure of the Federal Republic of Somalia; Federal level, State level, and Local level. BRA consists of 17 districts and these districts made up the city of Mogadishu. At the same time, Mogadishu is the capital of the Federal Republic of Somalia. BRA is responsible for managing functions of the region as well as functions of municipality-Mogadishu. The governor of the region is also the mayor of the city.

\subsection{Problem Statement}

In many developing and under-developing nations, low routine with regards to transparency, responsiveness, and participation to execute policies are the blockages for the accomplishment to give good governance and the achievement of improvement strategies (Woldeab et al., 2012). Along these lines, transparency, responsiveness, and participation are at the center point of governance and advancement forms as citizens reserve the option to realize what choices have been taken for their benefit, and they ought to have the way to potential activities when government neglects to release its duties. Research uncovers that low limit and responsibility of local officials, defilement and lease looking for are among others the difficulties towards guaranteeing good governance in local governments.

It states that the governance, administration and decision-making processes in the public sector are carried out with the cooperation and participation of all stakeholders and that the administrators act in a conciliatory, transparent, accountable, effective and responsible management approach (Toksöz, 2008: 17). Local governments have the responsibility to reach low levels of the community. It plays an important role in delivery services on behalf of the state to the citizens. These include education, healthcare, registration, and more other services not limited to these (Anna \& Lissa, 2016).

In the literature, so far no study focused on the role of local good governance on conflict resolution in Benadir municipality. So that researcher in this study will consider the role of; local government's public participation, accountability, transparency and equity on conflict resolution in Benadir Municipality, Mogadishu-Somalia.

\subsection{Objectives of the Study}

In this study, general and specific objectives will be discussed.

\subsubsection{General Objective}

The general objective of this study was to investigate the role of good governance on conflict resolution at the local level in the Benadir Municipality.

\subsubsection{Specific Objectives}

To reach the objectives of the study, four specific objectives will be asked to the participants:

1. To study the role of local government participation in conflict resolution in the Benadir Municipality.

2. To explore the role of local government accountability on conflict resolution in the Benadir Municipality.

3. To search the role of local government transparency on conflict resolution in the Benadir Municipality. 
4. To assert the role of local government equity on conflict resolution in the Benadir Municipality.

\subsection{Research Questions}

The study focuses on the following questions

1. What is the role of local government participation in conflict resolution in the Benadir Municipality?

2. What is the role of local government accountability on conflict resolution in the Benadir Municipality?

3. What is the role of local government transparency on conflict resolution in the Benadir Municipality?

4. What is the role of local government equity on conflict resolution in the Benadir Municipality?

\subsection{Conceptual Framework}

The below conceptual framework was created to illustrate the relationship between the independent and dependent variables this study is carrying out. The dimensions or variables of the independent variable include local government's public participation, local government's accountability, local government's transparent and local government's equity whereas the dependent variable in this study is conflict resolution.

\begin{tabular}{|c|c|}
\hline Independent Variable & $\underline{\text { Dependent Variable }}$ \\
\hline Good Governance & Conflict Resolution \\
\hline $\begin{array}{c}\text { Local Government } \\
\text { Public Participation }\end{array}$ & \\
\hline $\begin{array}{c}\text { Local Government } \\
\text { Accountability }\end{array}$ & Local Conflict \\
\hline $\begin{array}{c}\text { Local Government } \\
\text { Transparency }\end{array}$ & Resolution \\
\hline $\begin{array}{c}\text { Local Government } \\
\text { Equity }\end{array}$ \\
\hline
\end{tabular}

Figure 1.6.1. Conceptual Framework of the study 


\section{REVIEW OF THE LITERATURE}

This part emphasizes a review of articles about good governance practice and conflict resolution that were printed in various international journals. This section also matches up to the results of the articles while these studies were employed in different situations, times and geographies according to the environment. The concept was first referred to as "good governance" in a report by the World Bank published in 1989. The term, good governance, first showed up being developed circles in a much-cited text on the World Bank's 1989 report: Sub-Saharan Africa: From Crisis to Sustainable Growth. A Long-Term Perspective Study. After that, the term good governance became a controversial concept around the world especially developing countries and under developing countries. So far, the definition of this concept is controversial in the literature.

The concept of governance can be dealt with in three dimensions: systemic, political and managerial. Systemically, governance is defined as a broader concept than the government, depicting the institutionality and classical structure of political power. Governance in the political dimension refers to the legitimacy and democratic governance of political power, as well as the participation of citizens in government outside elections. In the administrative dimension, what is meant is to create a potential for positive change in terms of ensuring quality and transparency in public services (Demirel, 2010).

The idea of governance is grounded in an aggregate activity way to deal with issues and resolve. This methodology includes coordinating partners and society to start reconciliations of conflicts among the community by including the state as well as numerous free associations (public, private, and civil society) that some way or another add to the quest for the public intrigue (Kamarac, 2002).

World Bank, International Monitory Fund (IMF), United Nation Development Program (UNDP), and many other institutions locally or internationally used different measurements of good governance. The standard of good governance, utilized this investigation, alludes to the standards of good governance proposed by UNDP in 1997, these principles of good governance include participation, rule of law, transparency, responsiveness, consensus orientation, equality, effectiveness and efficiency, accountability, and strategic vision. According to the objectives of the articles, this study carried out four of the principles of good governance which include participation, accountability, transparent and equity.

\subsection{Local Government Public Participation}

In terms of good governance principles, participation is one of the main principles of good governance. It encourages the citizen to have participated in the political process of the country. This participation can be a form of direct participation i.e. citizen's direct participation or it can be indirect means through representatives of citizens (Kaufman, Kraay, \& Mastruzzi, 2006). The concept of participation accentuates the collaboration among different sectors in the country such as civil based organization, business sectors, government, and other sectors. Good governance principles encourage the inclusiveness of all government activities like planning, policymaking, decision-making process and so on. Moreover, participation can be referred to when people are participating in government activities actively. 
Generally accepted point of view is the devolution power of service delivery to local government from the central, it helps to utilize and allocate resources effectively avoiding duplication of resources and delay of service provision. Also, this ensures addressing and matching real needs and problems of the community and facilitates prioritizing local needs. Abdi \& Dirie (2017) discussed in their research local participation at the stage of decision making in the municipality of Mogadishu. The study aimed at the extent to which community participation has the role decision-making process in Mogadishu. Researchers found that the local community has the will to elect local leaders and regional leaders to exercise their citizenship rights which encourages transparency and accountability and feeling ownership of government. However, the study found that the existence of some factors that hinder Mogadishu's local government participation in the decision-making process like the absence of trust among sides, fear of community participation due to the insecurity in the city, lack of proper skills, limited resources, inadequate training of local authorities toward community mobilization. The study concluded the role of the local community in terms of the local government decision-making process is very limited, minimal and very weak.

Good governance makes an obligation to the public officials to have political and administrative knowledge, skills and ability to make functioning their duties in the demand of citizens. It is also required to have enough knowledge about the rules and regulations that surround their responsibilities. Respecting the supremacy of what people agreed is also important in public governance. Ahmed \& Koech (2019) explored the effect of public governance relating to the service delivery in Benadir municipality, Somalia. Their study aimed to evaluate the influence of public accountability, public participation, rule of law and public transparency on Benadir municipality service delivery. In their article, they focused on four service delivery: direct service delivery which implies from central to the people, privatization which gives meaning of privatizing government functions to private companies which is responsible to deliver services, decentralization which relates delegating responsibilities to local-level institutions, and alternative service delivery which is public-private partnerships which based on contracts. The result of the study specified the relationship between four variables; rule of law, transparency, accountability, and participation have a statistically positive effect on service delivery in Benadir municipality.

Corruption is one of the main challenges many countries in Africa including Somalia. Corruption is not only about misusing government resources, but it can also be power abuse. Accordingly, Mohamud \& Ibrahim (2019) employed local governance and poverty reduction in Mogadishu's local government. The study revealed local governance, accountability, community participation, and responsiveness have a positive strong relationship on poverty reduction in the Mogadishu municipality and the increase of each will have a positive impact on eliminating poverty.

Manthwa \& Ntsoane (2018) examined disputes and conflicts at the local government at the election process and the role of public participation mechanism to resolve these conflicts in Moutse-South Africa. The study discussed the importance of participation in people to the issues concerns and affects their life. Researchers affirmed that the active participation of the community in activities can accurately encourage people to participate in a reconciliation process to solve their issues. Public participation is one of the fundamental principles of democracy and it important people to participate in the decision-making process. 


\subsection{Local Government Transparency}

Another key component of good governance theory is transparency. It emphasizes that the procedure of basic decision making, definitive choices came to and the recognition of such choices must be done in similarity with rules and guidelines. It stipulates that adequate information freely dispersed in such a way and medium, that can without much of a stretch be comprehended and transparency to the general population that will be influenced and who will guarantee consistency (Sheng, 2012). With transparency, choices made by the administration are known and the usage of the choices keeps standards and guidelines that are openly accessible and reasonable to the individuals who are influenced by the choices and even people in general. Transparency is the ability that individuals can access timely, understandable, relevant, qualified, reliable information regarding the decisions taken by states on economic, political and social issues, the status of property of organizations operating in the private sector, and the activities of international organizations (Kuzey, 2003).

Transparency can be categorized into; the availability of policy that is used to monitor, right to access information to know every aspect of government functions and how different branches of government make check and balance especially executive branch and the legislative branch. The government should invent mechanisms that citizens can get information like publication, broadcasting and so on. In the period of provincial self-governance, the utilization of good governance is a pressing issue in the endeavor to accomplish local good governance that is viable, proficient, and free of corruption (Pratiwi \& Sari 2017).

Perona \& Coll (2014) emphasized budget transparency in the 110 largest local governments in Spain. Their study focused on four factors that determine budget transparency in municipalities; demographics of social, economic, political and budgetary. During their study, they emphasized six areas to better understand the transparency of budget in local government. First, the cooperation of municipal information; second, cooperation between local government and citizens; third, resource transparency, local government procurement, planning and decision making the process of urban planning and implementation, and factors showing the new rule of transparency. The findings of the study show imbalance of budget and population have an influence on the degree of transparency. On the opposite, lack of job opportunities, liability per capita, and regional resources have a negative effect on decreasing the level of transparency in local government. An economic indicator that influences transparency is the unemployment factor because the more unemployment rate is high the transparency index will be low (Perona \& Coll, 2014).

Transparency plays a crucial role in local government to give updates to the citizens. Tavares \& Crus (2014) investigates determinants of transparency in local government, using the Portuguese municipality's transparency index. The purpose of their study was to know even if the capacity, leadership and political qualities of local government are the main drivers of transparency. The main question of their research was related to finding out the drivers of transparency in the municipality. Researchers alleged gender has positive effect transparency in local government, municipalities in which females are the top-level have good transparency level, education also another driver of transparency the more education level is high the more transparency level is high. Commitment and political will of mayor is also important another factor of transparency. Electoral competition, political ideology, the administrative capacity have a significantly positive relationship to the transparency at the local level. Remarkably, nonexistence competition of 
leadership position is the only factor that undermines the effectiveness of local government transparency.

Abdisalem (2015), explored the feature of good governance on land management in the case of Naeder Adet Woreda, Ethiopia. He evaluated the result of good governance for responding to timely and transparency. Practicing good governance principles like transparency and responsiveness in Woreda level is not pleasing and minimal or no pertained in the region. Factors that hamper to pertain transparency and responsiveness include corruption, poor public teaching, poor mechanisms of monitoring and evaluation, low capacity injection and lack of collaboration among stakeholders. Khalid, Alam \& Said (2016), assessed the level of good governance practice in Malaysia government institutions. The study target 109 participants from 24 federal ministries, to analyze the data seven-point Likert scale, descriptive statistics and path measurement tools were used. The study resulted in the level of using anti-fraud mechanisms were low. According to the service departments, engineer groups showed satisfactory levels while the health department practiced good governance unsatisfactory level or low level.

\subsection{Local Government Equality}

Good governance includes ensuring the privilege of all persons to chances to improve or keep up their prosperity fairly and comprehensively. This point may be the most significant standard of Good governance since it necessitates that all choices of an association are made inside a system that is outward-looking and future-arranged. The standard ensures the accompanying: respect of the human individual, equality of rights and opportunity from any segregation. It is widely inclusive and incorporated for all individuals from the general public. It likewise underlines the prosperity of the general public which is for the most part supported by the feeling of having a place with the general public by all citizens just as a sentiment of belongingness as partners in the general public. This, therefore, stipulates or guarantees that each citizen is given equal access to better his or her lot and furthermore to improve his or her prosperity in the general public (Grindle, 2004).

Sunday, Francis \& Abubakar (2018), examined the role of local government on service delivery in Nigeria using content analysis. Delivering service to the citizen is the constitutional mandate of local government in Nigeria. They concluded and recommended to the local government in Nigeria to put efforts to overcome challenges that hinder to reach good performance and this can be attained if the only local government and local people work hand-to-hand and serve to the people effectively, fairly, timely and satisfactory manner.

Alemie \& Mandefro, (2018) examined the role of local mechanisms of conflict resolution to sustain the social harmony and powering community in Alefa district-Ethiopia. The study aimed to explain the indigenous mechanisms for conflict resolution in the district. The study used qualitative research methods and thematic tools were used to analyze data. The findings of the study affirm that local mechanisms for conflict resolution are more accessible to the local people than dealing with the process of formal court systems. Indigenous mechanisms use public discussions to gather information and make clear causes of conflict in the community to reach consensus. The most wanted result of indigenous mechanisms of conflict resolution is to get social agreement, solidarity and to reach consensus through social dialogue and avoid disintegration in the community. The study revealed indigenous elements in the community like social harmony, solidarity, transparency, respect, coexistence, and tolerance are important 
principles for conflict resolution. The study also found some limiting factors of the indigenous implementation like lack of a clear policy direction which encourages the usage of this mechanism.

The researchers mentioned some advantages of indigenous mechanisms. The advantages of these mechanisms include easy, immediate, affordable and understandable to the local community including marginalized groups. Unlike the formal court process, indigenous mechanisms are useful because they reduce delay and minimizes the cost of reconciliation conflict. Indigenous mechanisms facilitate to attain long term conflict resolution, peace building, and approachable justice. This concept based on using traditional mechanisms of conflict resolution like norms, beliefs, etc. The study suggests to build up clear policy frameworks that make it easy to conduct indigenous mechanisms in the local people. In addition to this, the study recommends to create sound-full of enforcement of this mechanism and to respect and obey the decisions of elders for conflict resolution (Alemie \& Mandefro, 2018).

Another study in Nigeria focused on the sound position of local government administration toward effective conflict resolution. This study paid attention to describe the root causes of neverending local government conflicts in Nigeria. Furthermore, the study considered conflicts between law-making organ and executive organ of the government as well as conflicts involving politicians and local government officials. Researchers pointed out the main drivers of conflict in local government, first, political factor because most of the politicians seeks to the position to shortest way of becoming wealthy, secondly, economic factor which deals with misappropriation of resources in local government, thirdly, socio-cultural factor, fourth, natural factor which relates to the inevitableness of conflict as a part institutional life where different people come together, Fifth and last inter-departmental or territorial role conflict between departments of local government or among local governments in Nigeria (Jatto, Mahuta \& Isah, 2013).

Besides, researchers proposed some strategies that can be used to lessen conflicts in local governments in Nigeria. Strategies include; council members of local government should avoid conducting unfairness when a conflict between officials arises it should not be overstressed, they should always seek mechanisms used to reduce conflicts, and employees should avoid conflicts during serving the people. Jatto, Mahuta, and Isah (2013) concluded and suggested in their study to pay attention multi-cultural and diversity of people, consideration of equality, identification and keeping away conflict situations, to give training and capacity building local government officials and concerning socio-economic factors of local government employees in Nigeria. Notably, reforms of local governments in Nigeria due to the conflict have yet not reached in most favorable levels of service providing.

Salum (2017), explored mechanisms used to manage conflicts local government authorities in Tanzania, particularly the study used Bukoba municipality as a case study, Tanzania. The findings of the study showed that conflicts between councilors and workforce happen because of inequality of education, finishing projects beyond the planned time, self-interest, shortage of resources and pessimistic attitude toward goals, and intervention on work jurisdictions between two parties. Conflicts that occur in local government cause duplication of resources, employee turnover and resignation, low self-esteem and delay in project completion. Some mechanisms used to solve these issues include meetings, collaboration, negotiation, and mediation. 
Ahmed \& Ibrahim (2019), evaluated the regional building and the role of local government case of Benadir region-Somalia. The study found administrative reform has a significant relationship with the regional building. In terms of economic development if the local government manages local revenue effectively it can contribute to the region and country economic development. To achieve objectives of local government study recommends creating a sound workplace, train, and motivate local government service providers. Also, Mohamed \& Ikinya (2019), conducted a study about aspects that affect delivering service to the citizens in the Benadir Local government. The researchers explored four different dimensions to the conduct of this study; public participation, accountability, transparency, and equity on the quality of service delivery. In the finding and conclusion section, they reported the combination of four measurements under the independent variable have positive and statistically related to the dependent variable of public service delivery. Implementation of participation, accountability, transparency, and equity has a positive significant relationship to the dependent variable which service delivery.

\subsection{Local Government Accountability}

Accountability is one of the foundations of good governance. Accountability is a complex and multi-faceted idea that is hard to characterize in exact terms. Nonetheless, accountability is the procedure using which an individual or gathering can be considered answerable for their lead (Ebrahim, 2003). The government is accountable to the public at large. At the local level, every government official should be accountable to the citizen that the government is serving. Consideration of accountability may include performance accountability, budget accountability, and all other activities of local government. The greater accountability general society, particularly public officers and authoritative bodies have, the higher the degree of good governance will be. In such a manner, good governance requires the work of both law and morals to upgrade the accountability of people and institutions (Keping, 2018). The concept of accountability underlines that all sectors including the business sector, community-based organization, public sector, universities, media, and every person who is a responsible group of people are to be made accountable to the public in general (Rotberg, 2004; Rothstein \&Teorell, 2008).

Accountability can be ordered as far as horizontal, vertical, social and political systems. Thecontemporaryroles of civilsociety on promoting good governance such as accountability, rule of law, transparency, responsiveness, and participation are very important in every country especially post-conflict countries like Somalia. Ibrahim \& Lewa (2019) evaluated the role of civil society in promoting good governance in Somalia. They claimed that civil society in Somalia is not enough active to perform expected roles. The study revealed that there is a positive correlation between predictors; public participation, accountabilily, and peacebuilding on the dependent variable of good governance.

Kluvers \& Tippet (2010) asserted empirical research to know the perception of people within the local government of Victoria-Australia. 78 municipalities were collected data and targeted administrators and councilors to get their perception of accountability. As they discussed accountability has twofold; political or public accountability which deals with fundamental principles and matters concern democracy and people's trust; and managerial accountability which focuses daily activities in the organization. Accountability in the public sector is more complex than accountability in the private sector. Researchers discussed in their study four factors: information, value, enforcement, and relationship. Availability of information for 
everyone is important for accountability, reporting to the public improves accountability. The knowledge of people and service providers toward the concept of accountability is also important. To be accountable and enforcement of laws in local government encourages accountability.

Nofianti \& Susanti (2014), evaluated aspects influencing the implementation of good government governance and their implications for the performance of accountability in Riau Province, Indonesia. The study aimed to find good government governance implementation on the influence of performance accountability. The study found the effective implementation of good government governance has a significant influence on the performance of accountability in local government institutions. The study also reached the main challenges of local government to practice good governance and these challenges include collusion, corruption, nepotism, and lack of actual commitment to provide basic services to the people.

Dayanandan (2013), carried out a study about good governance practice to reach a good performance of the community organizations in Halaba district, Ethiopia. The study aimed to assess the impact of governance practice in Halaba district on the community organizations for better performance. The finding of the study shows poor business participation in the district, absence of awareness for management, corruption, the nonexistence of democracy, duplication of resource and uncertainty of responsibility and poor sense of ownership. In terms of the binary logistic analysis found that a significant positive relationship of four pillars of good governance (participation, accountability, transparency, and rule of law) to the result of performance in the community organizations.

Silima (2016), conducted a study about good governance and conflict resolution. This study focused on the context of Africa. The main purpose of the article was to investigate and shed-on light on the applicability to practice good governance in Africa. The article confirms the view of good governance encourages respect for human rights and building institutions that facilitate good governance and conflict resolution in Africa. A good point of citizens understanding, working together, and participation is important to establish a democratic government that practices principles of good governance. This article classifies good governance types into democratic governance, corporate governance, and global governance. Silima concludes his study recommendations of good governance practice and conflict resolution in Africa. In terms of good governance practice, the study recommends institutions of good governance should be placed in Africa, principles, and laws should be followed as planned. On the side of conflict resolution study also recommends stakeholders of community and government should be ready to solve their disagreement which causes conflict in Africa to service government to the people soundly, fairly and effectively.

\section{METHODOLOGY}

\subsection{Research Design}

This article used a quantitative research design to explore the role of good governance on conflict resolution at the local level in Benadir municipality. Also, to measure the knowledge of the participants toward the objectives of the article descriptive statistics were analyzed. Furthermore, thisstudy used inferential statistics to investigate the relationship between independent variables; 
local government public participation, accountability, transparent, equity and dependent variable which is conflict resolution.

\subsection{Research Population and Sample size}

The target population of the study was 150 participants from the departments of Benadir municipality and civil society. To find a sample from the participants Slovin's formula was used.

$\mathrm{n}=\frac{\mathrm{N}}{1+N a^{2}} \quad \mathrm{n}=\frac{\mathbf{1 5 0}}{\mathbf{1 + 1 5 0}(\mathbf{0 . 0 5})^{\wedge} \mathbf{2}}=109$ Whereby;

$\mathbf{N}$ : stands the population, $\mathbf{n}$ : stands the sample, a: stands acceptable error

\subsection{Sample Procedure and Research Instrument}

This study used stratified random sampling under the probability sampling method. It refers probability sampling procedure in which the population is divided into two or more relevant strata, therefore, the main purpose for selecting stratified random sampling is to ensure equitable representation of each stratum in the sample at the same time, the reasons for using this sampling procedure is to ensure that sub-group are proportionately represented, accounts for difference in sub-group characteristics. To gather data from participants questionnaire was used. Five points Likert Scale will be employed in this questionnaire. This method encompasses up to five disagree which is designed; 1 for strongly disagree, 2 for disagree, 3 neutral, 4 agree and 5 for strongly agree. Mean, standard deviation, correlation, Multiple regression, and ANOVA table will be used in this study. Statistical Package for Social Science SPSS 21.0 is used to analyze data.

\subsection{Reliability and Validity of the Instrument}

To ensure the consistency and soundness of the instruments used in this study reliability and validity were employed.

\subsubsection{Reliability}

This study tested reliability to sustain the consistency of the findings and the validity using by SPSS. In this study, Cronbach Alpha is tested to know the entire consistent and reliability of the data. The reliability statistics using Statistical Package for Social Science (SPSS) are used with the help of Cronbach Alpha it was detected that 26 items of the questionnaire were $73 \%$ that means that the information is credible. A value is higher than $50 \%$ is considered sufficient and in this case, it is $73 \%$.

Table 3.4.1. Reliability Statistics

\begin{tabular}{|c|c|}
\hline Cronbach's Alpha & N of Items \\
\hline .729 & 26 \\
\hline
\end{tabular}

\subsubsection{Validity}

To assure the validity the researcher employed Kaiser-Mayor-Olkin (KMO) and Bartlett's Test of Sphericity. The result is shown in the below table 3.4.2.1. As the result indicated KMO shows a value of 0.537 , this is higher than 0.5 for this reason satisfactory index. On the other hand, the 
test of Sphericity is shown 0.000 which is less than 5\%. The results KMO and Bartlett's Test of Sphericity have shown that there is a highly significant relationship between variables.

Table 3.4.2. KMO and Bartlett's Test

\begin{tabular}{|c|c|c|}
\hline \multicolumn{2}{|c|}{ Kaiser-Meyer-Olkin Measures of Sampling Adequacy. } & .537 \\
\hline Bartlett's Test of Sphericity & Approx. Chi-Square & 240.234 \\
\hline & Df & 10 \\
\hline & Sig. & .000 \\
\hline
\end{tabular}

\section{RESULTS}

This section reports descriptive statistics of the study, correlation of the variables, regressions, ANOVA tables, regression coefficient, discussion, conclusion, and recommendations of the study.

\subsection{Descriptive Statistics of Good Governance and Conflict Resolution}

This section analyzes and discusses the result of the study. During the analysis of the data, this section focuses on descriptive statistics, a correlation between variables, regression analysis, ANOVA table, and coefficient correlation of the variables. Mean index, standard deviation and interpretations of questions will be carried out in this section. The independent variable (IV) contains four variables; local government participation, accountability, transparency, and equity. Each variable possesses separate questions to measure the knowledge of participants toward the concept of the topic. Besides this, the dependent variable (DV) also contains questions intended to measure the dependent variable.

As shown in the table below of 4.1, the first independent variable of the study was local government public participants. To measure their knowledge about this concept participants were asked if the local government's public participation has an impact on conflict resolution participants. Respondents were agreed on this objective with an overall mean of 3.64 and a standard deviation of 0.611 , this implies that the local government's public participation has a positive impact on conflict resolution at the local level. Furthermore, the accessibility of community participation in the peace building process eliminates conflicts in the community and fosters community cohesiveness. The second variable of independent variable was local government accountability, to get the perception toward this variable participants were asked if the local government's accountability has a positive role in conflict resolution at the local community. Respondents revealed 3.85 and 0.611 of overall mean and standard deviation respectively as the below table shows. This indicates the availability of local government's accountability will have a positive role in conflict resolution at the local level in Benadir municipality.

According to the third dimension of the study, participants were asked if the local government's transparent has a role of contribution to the conflict resolution process, participants agreed with the average mean 3.82 and standard deviation of 0.586 . This specifies that the existence of 
transparency in local government has a contribution to the conflict resolution process at the local level. Whereby, the last independent variable was local government equity. Participants were agreed with this variable with the average of mean and standard deviation (mean 4.73 and std. deviation 0.400). On the other hand, the dependent variable of the article was conflict resolution, under this variable seven questions were asked to the participants and they revealed an overall mean of 3.78 and a standard deviation of 0.458 . This indicates that conflict resolution is vitally important at the low level in Benadir municipality. And also, this designates the importance of community cohesiveness and trust in the community as well as in the administration.

Table 4.1: Descriptive Statistics of Variables

\begin{tabular}{|l|c|c|c|}
\hline Variables & Mean & Std. Deviation & Interpretation \\
\hline Public Participation & 3.64 & .611 & Agreed \\
\hline Accountability & 3.85 & .611 & Agreed \\
\hline Transparent & 3.82 & .586 & Agreed \\
\hline Equity & 3.74 & .400 & Agreed \\
\hline Conflict Resolution & 3.78 & .458 & Agreed \\
\hline
\end{tabular}

Source: Primary Data, December 2019 C)

\subsection{Correlation between Good Governance (IV) and Conflict Resolution (DV)}

A coefficient correlation was employed to know the relationship between independent and dependent variables. The correlation analysis is critical for understanding the relationship between independent variables and dependent variables. In this study, good governance stands as an independent variable while conflict resolution represents a dependent variable. The result portrayed in table 4.2. The local government public participation and conflict resolution at the local level have a positive correlation of $60.9 \%$ as the result indicates $(\mathrm{r}=0.609, \mathrm{p}=.000)$. Furthermore, local government accountability has $56.4 \%$ moderately positive correlation with the conflict resolution $(\mathrm{r}=0.564, \mathrm{p}=.000)$, while local government transparent has statistically $40.2 \%$ weak positive correlation with the conflict resolution $(\mathrm{r}=0.402, \mathrm{p}=.000)$ and local government equity has also 58\% moderate positive correlation with conflict resolution at local level $(\mathrm{r}=0.580$, $\mathrm{p}=.000$ ). The result shows the correlation of all variables have significant positively correlated as the p-value is less than 0.05. This indicates the positive correlation between independent variables of local government participation, accountability, transparency and equity and the dependent variable of conflict resolution. 
Table 4.2.: Correlations of the Independent Variables and Dependent Variable

\begin{tabular}{|c|c|c|c|c|c|c|}
\hline \multicolumn{7}{|c|}{ Correlations } \\
\hline & & $\begin{array}{c}\text { Public } \\
\text { Participatio } \\
\text { n }\end{array}$ & $\begin{array}{l}\text { Accountabilit } \\
\text { y }\end{array}$ & $\begin{array}{l}\text { Transparenc } \\
\text { y }\end{array}$ & Equity & $\begin{array}{c}\text { Conflict } \\
\text { Resolution }\end{array}$ \\
\hline \multirow{3}{*}{$\begin{array}{l}\text { Public } \\
\text { Participation }\end{array}$} & $\begin{array}{l}\text { Pearson } \\
\text { Correlation }\end{array}$ & 1 & .121 & $.325^{* * *}$ & $.708^{* *}$ & $.609^{* *}$ \\
\hline & $\begin{array}{l}\text { Sig. (2- } \\
\text { tailed) }\end{array}$ & & .211 & .001 & .000 & .000 \\
\hline & $\mathrm{N}$ & 109 & 109 & 109 & 109 & 109 \\
\hline \multirow{3}{*}{$\begin{array}{l}\text { Accountabilit } \\
\text { y }\end{array}$} & $\begin{array}{l}\text { Pearson } \\
\text { Correlation }\end{array}$ & .121 & 1 & .161 & $.420^{* *}$ & $.564^{* *}$ \\
\hline & $\begin{array}{l}\text { Sig. (2- } \\
\text { tailed) }\end{array}$ & .211 & & .095 & .000 & .000 \\
\hline & $\mathrm{N}$ & 109 & 109 & 109 & 109 & 109 \\
\hline \multirow[t]{3}{*}{ Transparent } & $\begin{array}{l}\text { Pearson } \\
\text { Correlation }\end{array}$ & $.325^{* *}$ & .161 & 1 & $.482^{* *}$ & $.402^{* *}$ \\
\hline & $\begin{array}{l}\text { Sig. (2- } \\
\text { tailed) }\end{array}$ & .001 & .095 & & .000 & .000 \\
\hline & $\mathrm{N}$ & 109 & 109 & 109 & 109 & 109 \\
\hline \multirow[t]{3}{*}{ Equity } & $\begin{array}{l}\text { Pearson } \\
\text { Correlation }\end{array}$ & $.708^{* *}$ & $.420^{* * *}$ & $.482^{* *}$ & 1 & $.580^{* *}$ \\
\hline & $\begin{array}{l}\text { Sig. (2- } \\
\text { tailed) }\end{array}$ & .000 & .000 & .000 & & .000 \\
\hline & $\mathrm{N}$ & 109 & 109 & 109 & 109 & 109 \\
\hline \multirow[t]{3}{*}{$\begin{array}{l}\text { Conflict } \\
\text { Resolution }\end{array}$} & $\begin{array}{l}\text { Pearson } \\
\text { Correlation }\end{array}$ & $.609^{* *}$ & $.564^{* *}$ & $.402^{* *}$ & $.580^{* *}$ & 1 \\
\hline & $\begin{array}{l}\text { Sig. (2- } \\
\text { tailed) }\end{array}$ & .000 & .000 & .000 & .000 & \\
\hline & $\mathrm{N}$ & 109 & 109 & 109 & 109 & 109 \\
\hline
\end{tabular}

Source: Primary Data, December 2019 (C) 


\subsection{Regression Analysis}

As shown in the regression table of 4.3, the first important value is $\mathrm{R}$-value which shows the impact has variables of local government participation, accountability, transparent and equity on conflict resolution. In this case, the $\mathrm{R}$ shows that the variables are $80.4 \%$ predicting the dependent variable. The $\mathrm{R}$ square explains that there is variance in the dependent variable that is conflict resolution that is brought by local government participation, accountability, transparent and equity. The model explains $64.7 \%$ of the variance (Adjusted R square equals 0.633 ) on conflict resolution. This indicates that $64.7 \%$ of the relationship is explained by local government participation, accountability, transparent and equity while the rest $35.3 \%$ is explained by other factors that are not employed in this study.

Table 4.3.: Model Summary

\begin{tabular}{|l|c|r|r|rl|}
\hline \multicolumn{5}{|c|}{ Model Summary } \\
\hline Model & R & R Square & $\begin{array}{c}\text { Adjusted R } \\
\text { Square }\end{array}$ & Std. Error of the Estimate \\
\hline 1 & $.804 \mathrm{a}$ & .647 & .633 & & .277 \\
\hline \multicolumn{3}{|c|}{ a. Predictors: (Constant), Equity, Public Participation, Transparency, Accountability } \\
\hline
\end{tabular}

Source: Primary Data, December 2019 ㄷ

\subsection{Analysis of Variance (ANOVA)}

ANOVA table is explaining the variance that is brought in conflict resolution with the help of local government participation, accountability, transparent and equity. The 14.631 out of 22.626 is explained by the variables. The remaining number is explained by other variables that were not included in the research study. The significance value is below 5\% that is showing the model is good for fit explaining the relationship that is present among the variables.

Table 4.4: ANOVA Table

\begin{tabular}{|c|c|c|c|c|c|c|}
\hline \multicolumn{7}{|c|}{ ANOVA $^{a}$} \\
\hline & del & $\begin{array}{l}\text { Sum of } \\
\text { Squares }\end{array}$ & $\mathrm{df}$ & $\begin{array}{l}\text { Mean } \\
\text { Square }\end{array}$ & $\mathrm{F}$ & Sig. \\
\hline \multirow[t]{3}{*}{1} & Regression & 14.631 & 4 & 3.658 & 47.583 & $.000^{\mathrm{b}}$ \\
\hline & \multirow{2}{*}{$\begin{array}{l}\text { Residual } \\
\text { Total }\end{array}$} & 7.995 & 104 & .077 & & \\
\hline & & 22.626 & 108 & & & \\
\hline \multicolumn{7}{|c|}{ a. Dependent Variable: Conflict Resolution } \\
\hline
\end{tabular}

Source: Primary Data, December 2019 (C) 


\subsection{Regression Coefficients}

The coefficients table shows the regression line formed based on the data that has been analyzed. The significance values for local government's participation, accountability, and transparency are below 0.05 and when the p-value is less than 0.05 that means we reject the null hypothesis and accept the alternative hypothesis. As the result indicates public participation, accountability, and transparency have a great impact on conflict resolution. However, the variable of equity is above 0.05 and when $\mathrm{p}$ is more than 5\% that means we reject the alternate hypothesis and accept the null hypothesis. The local government's participation is very much a strong factor in contributing to conflict resolution and peace building. The beta value shows the rate change brought by dimensions, the increase of one unit in public participation will contribute to the increase of $44.3 \%$ to the conflict resolution process. In terms of local government's accountability coefficient value is 0.394 implies an increase of a unit in local government accountability will contribute an increase of $39.4 \%$ in conflict resolution. Likewise, the beta coefficient of local government transparency is 0.157 and it signifies the increase of one unit in local government transparent will lead to an increase of $15.7 \%$ in conflict resolution. Lastly, the beta coefficient of equity is -0.179 denotes an increase in one unit of local government equity decreases by $17.9 \%$ in conflict resolution. This information is reliable and applicable in real situations as well as the information is showing that participation, accountability, and transparency are having a positive influence on conflict resolution and equity does not have a positive impact on the conflict resolution process.

Thus the predictive model provide by the research findings is as expressed below:

$\mathrm{Y}=0.720+0.443 \mathrm{X} 1+0.394 \mathrm{X} 2+0.157 \mathrm{X} 3+(-0.179 \mathrm{X} 4)$ Where:

$\mathrm{Y}=$ Conflict Resolution

$\mathrm{B}_{0}=$ Constant

$\mathrm{X} 1$ = Local Government Public Participations

$\mathrm{X} 2$ = Local Government Accountability

X3 = Local Government Transparency

X4 = Local Government Equity 
Table 4.5: Regression Coefficients

\begin{tabular}{|c|c|c|c|c|c|c|}
\hline \multicolumn{7}{|c|}{ Coefficients $^{\mathrm{a}}$} \\
\hline \multirow{2}{*}{\multicolumn{2}{|c|}{ Model }} & \multicolumn{2}{|c|}{$\begin{array}{l}\text { Unstandardized } \\
\text { Coefficients }\end{array}$} & \multirow[t]{2}{*}{$\begin{array}{l}\text { Standardized } \\
\text { Coefficients }\end{array}$} & \multirow[t]{2}{*}{$\mathrm{T}$} & \multirow[t]{2}{*}{ Sig. } \\
\hline & & B & Beta & & & \\
\hline \multirow[t]{5}{*}{1} & (Constant) & .720 & .269 & & 2.681 & .009 \\
\hline & $\begin{array}{l}\text { Public } \\
\text { Participation }\end{array}$ & .443 & .064 & .591 & 6.881 & .000 \\
\hline & Accountability & .394 & .050 & .526 & 7.851 & .000 \\
\hline & Transparency & .157 & .052 & .201 & 3.011 & .003 \\
\hline & Equity & -.179 & .115 & -.156 & -1.551 & .124 \\
\hline
\end{tabular}

Source: Primary Data, December 2019 C)

\subsection{Discussions, Conclusions and Recommendations}

This section discusses the findings of the study and concludes with the alignment of the research objectives. The main aim of the study was to explore the role of good governance on conflict resolution at the local level using Benadir municipality as a case study. Good governance stands for an independent variable while conflict resolutions represent the dependent variable in this study. The study used good governance into four indicators which were local government public participation, accountability, transparent and equity as an independent variable whereas conflict resolution was the dependent variable. The findings of the study indicated that the majority of the respondents agreed that the local government's participation, accountability, transparent and equity have a positive role in conflict resolution in the context of this study.

The first objective of the study was to study the role of the local government's participation in conflict resolution. To reach this objective six questions were asked to the participants and they agreed that the local government's public participation has a positive effect on conflict resolution (mean 3.64 and std. deviation 0.611). In terms of coefficient correlation, public participation has a moderately positive correlation with conflict resolution $(\mathrm{r}=0.609, \mathrm{p}=.000)$. Furthermore, to study the degree of contribution of public participation in the conflict resolution regression coefficient was analyzed. The beta coefficient of public participation is 0.443 which implies the increase of a unit in local government's public participation leads a $44.3 \%$ increase in conflict resolution. This indicates that the local government's public participation in Benadir municipality is essential in the conflict resolution process.

The second objective of the study was to explore the role of the local government's accountability in conflict resolution. To achieve this objective four questions were asked to the respondents and they revealed that the local government's accountability has a positive role in the conflict resolution process (mean 3.85 and std. deviation 0.611). Additionally, the relationship between 
the local government's participation and conflict resolution was analyzed. The result is shown that accountability has a moderately positive correlation with conflict resolution ( $\mathrm{r}=0.564$, $\mathrm{p}=.000$ ). Moreover, the regression coefficient was analyzed, the beta coefficient of accountability is 0.394 means the increase of one unit in the local government's accountability has a $39.4 \%$ influence increase in conflict resolution. This explains that the local government's accountability has a positive role in the conflict resolution process in Benadir municipality.

According to the third objective of the study was to know the role of local government transparency on conflict resolution. Five questions were asked participants to measure their knowledge about this dimension, they agreed that the local government's transparent has a positive effect on the conflict resolution process (mean 3.82 and std. deviation 0.586). To compute the correlation between the local government's accountability and conflict resolution Pearson Bivariate coefficient correlation was used. The result indicates that the coefficient correlation of $\mathrm{r}$ equal to 0.402 . This means that accountability has a weak correlation with conflict resolution $(\mathrm{r}=0.402, \mathrm{p}=.000)$. To know the level of accountability contributes to the conflict resolution process regression coefficient was analyzed. The regression coefficient of transparent is 0.157 , it implies the increase of one unit in the local government's transparent leads to a $15.7 \%$ increase in conflict resolution.

The last objective of the study was to assert the role of local government equity in conflict resolution. To attain this objective four questions were asked participants to know their perception toward this objective. Participants agreed on questions asked which means that local government's equity has a positive role in the conflict resolution process (mean 3.74 and std. deviation 0.400). In addition to this, to find the relationship between the local government's equity and conflict resolution correlation coefficient was analyzed. The result indicates that local government equity has a positively moderate correlation with conflict resolution $(\mathrm{r}=0.580$, $\mathrm{p}=.000$ ). Unlikely, the level of this variable contributes to the conflict resolution regression coefficient was conducted. The beta of equity is -0.157 which means the increase of one unit in local government equity leads to a $-15.7 \%$ decrease in conflict resolution. The result indicated that the variable of equity has a negative effect on conflict resolution in the context of this study targeted.

Finally, regressions analysis was employed as R-value shown local government participation, accountability, transparent and equity variables have impact on conflict resolution. The model explains $64.7 \%$ of the variance (Adjusted $\mathrm{R}$ square equals 0.633 ) on conflict resolution. This indicates that $64.7 \%$ of the relationship is explained by local government participation, accountability, transparent and equity while the rest $35.3 \%$ is explained by other factors that are not employed in this study.

The study concludes that the local government's participation, accountability, and transparency have positive effect and a positive correlation with the conflict resolution in Benadir municipality as the result indicated in the context of the study. On the other hand, the local government's equity has a week negative correlation to the conflict resolution in the context this study is targeted. 


\section{IJMA}

\section{The study recommended that:}

- Benadir municipality should adopt public participation policies such as accessibility of information, utilization of information and citizen's awareness of participation as a citizen's right to create platforms that local people can participate in activities, and contribute to a local level of local government's participation as well as conflict resolution.

- Benadir municipality should develop policies of local government's accountability like rules and regulations that will guide, policies against misconduct, the process of investigation wrong-doing and financial scrutiny to enhance local government's accountability and conflict resolution at the local level.

- Benadir municipality should create public transparency through creating policies of openness and honest, free and pluralistic media and information accessibility to enhance mutual trust between local people and local government.

- Benadir municipality should ensure gender balance, cultural diversity consideration and economic balancing to practice equity in local government. The study also recommends the Benadir municipality to adopt good governance principles at the local level to contribute a conflict resolution process in the community.

In future research, it will be interested to carry out mechanisms used to solve conflicts in the community since this study employed the role of good governance on conflict resolution at the local level using some principles of good governance.

\section{References}

Abdi, A. M., \& Dirie, A. W. (2017). Community Participation in Decision Making Process in Mogadishu Municipality. Mogadishu University Journal, (2), pp. 123-146.

Abdisalem, M. (2015). The Performance of Good Governance on Land Administration at Local / Woreda Level: The Case of Naeder Adet Woreda, Tigiray Region, Ethiopia. International Journal of Political Science and Development, 3(8). PP. 4-11

Ahmed, M. A., \& Koec, P. (2019). Influence of Public Governance on Service Delivery in Benadir Municipality, Somalia. International Journals of Academics \& Research (IJARKE Humanities \& Social Sciences Journal), 1(2). pp. 196-206

Ahmed, Z. A. S., \& Ibrahim, A. A. (2019). The Role of Local Government on Regional Building in Benaadir Region, Somalia. EPRA International Journal of Research and Development (IJRD), 4(4), pp. 104-107.

Alemie, A., \&Mandefro, H. (2018). Roles of Indigenous Conflict Resolution Mechanisms for Maintaining Social Solidarity and Strengthening Communities in Alefa District, North West of Ethiopia. Journal of Indigenous Social Development, 7(2), pp. 1-21.

Anna, M., \& Lissa, T. (2016). Governance, Local government, Accountability, and Service Delivery in Tanzania. Mzube University.

Dayanandan, R. (2013). Good Governance Practice for Better Performance of Community Organizations - Myths and Realities !! Journal of Power, Politics \& Governance, 1(1), pp. 10-26. 
Demirel, D. (2010). YönetişimdeYeniBirBoyut: E-Yönetişim. TürkIddareDergisi, (466), 65-94.

Ebrahim, A. (2003) "Making sense of accountability: Conceptual perspectives for northern and southern nonprofits," Nonprofit Management and Leadership 14, pp. 191-212.

Grindle, M. (2004). Good Enough Governance: Poverty Reduction and Reform in Development Countries. Governance: An International Journal of Policy, Administration and Institutions, 17(4), pp. 525-548.

Ibrahim, S. A., \&Lewa, E. (2019). Role of Civil Society on Promoting Governance in Somalia. International Journals of Academics \& Research, 1(4), pp. 25-32.

Jatto, T., Mahuta, M. M., \&Isah, S. (2013). Effective Resolution of Possible role Conflicts in Local Government Administration: A Panacea for Nation Building. IOSR Journal of Humanities and Social Science (IOSR-JHSS), 18(4), pp. 80-83.

Kamarck, E. C. (2002). Applying 21st-Century Government to the Challenge of Homeland Security, pp. 1-48

Katsamunska, P. (2000). The Concept of Governance and Public Governance Theories, 133-141.

Kaufmann, D., A. Kraay. And Mastruzzi, P. (2006). Governance Matters. World Bank Policy Research Working Paper, No. 2296, Washington, DC: World Bank. pp. 1-64

Keping, Y. (2018). Governance and Good Governance: A New Framework for Political Analysis. Fudan Journal of the Humanities and Social Sciences, 11(1), pp. 1-8.

Khalid, M. A., Alam, M., \& Said, J. (2016). Empirical Assessment of Good Governance in the Public. Economics \& Sociology, 9(4), pp. 289-304.

Khan, M. M., (2006). Dominant Executive and Dormant Legislature: Executive-Legislature Relations In Bangladesh, Dhaka: University Press Limited (UPL) \& New Delhi: South Asian Publishers. pp. 1-131

Kluvers, R., \&Tippett, J. (2010). Mechanisms of Accountability in Local Government: An Exploratory Study. International Journal of Business and Management, 5(7), pp. 46-53.

Kuzey, P. (2003). Şeffaflık ve İyi Yönetişim, İyi Yönetişimin Temel Unsurları, T.C.Maliye Bakanlı̆̆ı Avrupa Birliği Ve Dış İliş̧kiler Daire Başkanlığı Yayını, Ankara. 1-17. Retrieved 24 December 2019 http://debis.deu.edu.tr/userweb//hilmi.coban/şeffaflık.pdf

Manthwa, T. A., \&Ntsoane, L. S. (2018). Public Participation, Electoral Dispute and Conflict Resolution Mechanisms. Journal of African Elections, 17(2), pp. 105-124.

Mohamed, A. M., \&Ikinya, G. K. (2019). Factors Influencing Public Service Delivery in Banadir Local Government - Somalia. International Journals of Academics \& Research (IJARKE Business \& Management Journal), 1(2), pp. 11-25.

Mohamud, F. A., \& Ibrahim, A. A. (2019). The Role of Local Governance on Poverty Reduction in Mogadisho Municipality. EPRA International Journal of Research and Development (IJRD), 4(5), pp. 78-84.

Moller, B. (2009). The Somali Conflict: The Role of External Actors, DIIS Report 2009:03. Copenhagen: Danish Institute for International Studies. 
Nofianti, L., \& Susanti, N. (2014). Factors affecting implementation of good government governance ( GGG) and their implications towards performance accountability. Procedia Social and Behavioral Sciences, 164, pp. 98-105.

Perona, P. G., \&Coll, M. T. B. (2014). Budget Transparency in Local Government. UniversitatJaume I, pp. 2-35.

Pratiwi, D. A., \& Sari, M. E. P. (2017). An Analysis of Good Governance in the Public Service Sector of BATAM. Journal of Techno Social, 9(1), pp. 71-80.

Rotberg, R.I. (2004). Strengthening Governance. Washington Quarterly 38, pp. 71-81.

Rothstein, B. and J. Teorell. (2008). What is Quality of Government: A Theory of Impartial Political Institutions. Governance-An International Journal of Policy and Administration, 21, pp. 165-190.

Salum, V. S. (2017). Mechanisms of Conflict Management in Tanzania's Local Government Authorities : A Case of Bukoba Municipal Council. Journal of Public Administration and Governance, 7(3), pp. 269-286.

Sheng, Y.K. (2008). What is good governance? United Nations Economic and Social Commission for Asia and the Pacific (UNESCAP).Retrieved on July 2019 from http://www.unescap.org.

Silima, T. (2016). Good Governance and Conflict Resolution in Africa. Journal of Public Administration and Development Alternatives, 1(1), pp. 1-14.

Sunday, M., Francis, A., \& Abubakar, Y. (2013). Local Government and Social Service Delivery in Nigeria: A Content Analysis. Academic Journal of Interdisciplinary Studies, 2(2), pp. $455-462$.

Tavares, A. F., \& Cruz, N. F. (2014). The Determinants of Local Government Transparency: A Preliminary Analysis, ICEGOV.

Toksöz, F. (2008). İyi Yönetişim El Kitabi (1. Baskı). İstanbul: TESEV.

UNDP (1997). Governance to Support Sustainable Human Development. Program Information Bulletin Partnership for Governance Reform in Indonesia.

William, V., Victor, B., Krista, T., Piret, T., \& Lars. (2017). Changing public service delivery: learning in Creation, Policy and Society. 36 (2), 178 -194.

Woldeab, T, Degefa T, Fenta, M, and Bamlaku, A., (2012). "Governance and public service delivery": the case of water supply and roads services delivery in Addis Ababa and Hawassa Cities", Ethiopia Regional and Local Development Studies, Addis Ababa University

World Bank (1989). 'Sub-Saharan Africa. From Crisis to Sustainable Growth: A Long-term Perspective Study'. Washington, DC: World Bank. 